\title{
Axial spondyloarthritis in the USA: diagnostic challenges and missed opportunities
}

\author{
Abhijeet Danve ${ }^{1} \cdot$ Atul Deodhar $^{2}$ (D) \\ Received: 21 September 2018 / Revised: 3 December 2018 / Accepted: 6 December 2018 / Published online: 26 December 2018 \\ (C) The Author(s) 2019
}

\begin{abstract}
Axial spondyloarthritis (axSpA) is a chronic inflammatory rheumatic disease that primarily affects the sacroiliac joints and spine. Delayed or inadequate treatment may decrease quality of life and lead to poor long-term outcomes, including irreversible loss of spinal function. In this review, we discuss clinical practice related to axSpA within the USA, including prevalence, diagnosis, reasons for delayed/missed diagnosis, and suggestions for making early diagnosis. The US population prevalence of axSpA (0.9$1.4 \%)$ is higher than the diagnostic prevalence $(0.2-0.7 \%)$. Although the estimated diagnostic delay for axSpA is 14 years in the USA, the disease can be identified earlier if appropriately preselected patients are quickly referred to rheumatologists. Only $37 \%$ of patients with ankylosing spondylitis in the USA are diagnosed by rheumatologists; the remaining $63 \%$ are diagnosed by primary care (26\%), chiropractic/physical therapy (7\%), orthopedic surgery (4\%), pain clinics $(4 \%)$, acute care $(3 \%)$, and other settings (19\%). To help reduce diagnostic delay, non-rheumatologist-healthcare professionals are urged to refer patients with back pain and $\geq 1$ of $3 \mathrm{SpA}$ features (HLA-B27 positivity, current inflammatory back pain, or X-ray/MRI evidence of sacroiliitis) to a rheumatologist. Prevalence and diagnosis rates of axSpA are disparate in the USA due to the lack of awareness and knowledge among non-rheumatologists. Progress has been made in identifying hurdles causing diagnostic delays. Public health initiatives are needed to guide primary care physicians, physical therapists, chiropractors, and other specialists seeing patients with chronic back pain on methods for suspecting or identifying axSpA and early referral to rheumatologists.
\end{abstract}

Keywords Ankylosing spondylitis - Axial spondyloarthritis · Clinical practice in the USA · Inflammatory back pain . Non-radiographic axial spondyloarthritis · Referral strategy

\section{Introduction}

Axial spondyloarthritis (axSpA), a chronic inflammatory rheumatic disease primarily affecting the sacroiliac joints (SIJs) and spine, commonly presents in patients aged $<40$ years, with inflammatory back pain (IBP) as a presenting symptom [1-4]. The term axSpA encompasses both ankylosing spondylitis (AS) and non-radiographic axSpA (nr-axSpA), which are distinguished by the presence or absence of definitive sacroiliitis on plain radiographs [5]. Disease activity and

Atul Deodhar

deodhara@ohsu.edu

1 Department of Medicine, Yale University School of Medicine, New Haven, CT, USA

2 Division of Arthritis \& Rheumatic Diseases, Oregon Health \& Science University, 3181 SW Sam Jackson Park Road, Portland, OR 97239, USA impairment in quality of life (QOL) are similar between patients with AS and nr-axSpA [6]. Hence, treating both conditions with equal priority is important because early treatment improves symptoms, function, and inflammation as viewed by magnetic resonance imaging (MRI) [7]. Distinguishing between AS and nr-axSpA can be important for scientific and clinical research purposes, but this differentiation is generally not necessary or practical for diagnostic or treatment purposes in daily clinical practice $[5,8]$. Although the natural history of nr-axSpA is not fully understood, studies indicate that patients with nr-axSpA can experience progression to AS over time [9].

Many studies on prevalence, diagnosis, and prognosis of axSpA originate from Europe, and the clinical situation regarding these issues is less well understood in the USA. Interestingly, back pain, one of the cardinal symptoms of axSpA, is extremely prevalent in the USA [10], but there is limited information about which healthcare providers (HCPs) treat patients with back pain. The prevalence rates of 
rheumatoid arthritis (RA) and axSpA in the USA are similar $[11,12]$. As RA presents with pain and swelling of hand joints, it is easily recognizable by non-rheumatology HCPs. However, it is difficult to examine the back and SIJs of patients with axSpA. Also, axSpA is more challenging to diagnose because chronic back pain is highly prevalent in the general population and patients with axSpA account only for $5 \%$ of these individuals $[13,14]$. These factors cause underrecognition of axSpA that can result in a missed or late diagnosis, which, in turn, leads patients to have prolonged pain, stiffness, fatigue, and decreased mobility. Additional poor long-term outcomes include irreversible new bone formation in the axial skeleton, loss of spinal function, and reduced QOL $[1,15,16]$.

A few characteristics of back pain in axSpA and associated laboratory and imaging features can provide clues to the presence of the condition. Using these criteria as filters in patients with back pain may help non-rheumatology HCPs identify patients with suspected axSpA early and appropriately refer them to rheumatologists.

This review examines the US clinical situation of axSpA delayed/missed diagnosis and provides practical guidance on strategies for improving early diagnosis.

\section{Methods}

We included original articles concerning human studies published between January 1984 and June 2018. A targeted PubMed literature review used all possible combinations of the following terms: nr-axSpA, AS, diagnosis, prevalence, classification criteria, comorbidities, practitioners, imaging, x-ray, MRI, computed tomography, and IBP. Titles, abstracts, and full reports of the resulting articles were screened for relevance. Search results were enhanced by reference citations in articles identified in initial searches and based on the authors' familiarity with the published literature. Articles were selected if they provided insight into the US clinical practice situation regarding the prevalence or diagnosis of axSpA or reasons for delayed/missed diagnosis.

\section{US prevalence of AxSpA}

Varying diagnostic and population prevalence findings for axSpA have been reported by US studies. A retrospective chart review of Mayo Clinic (Rochester, MN, USA) records from 1935 to 1973 found the prevalence of AS to be 129 per 100,000 in a predominately white population [17]. An updated study of patients from Rochester, MN, which examined records from 1935 to 1989 , reported the incidence of AS to be 7.3 per 100,000 person-years [18]. In 2008, the National Arthritis Data Workgroup reported the prevalence of AS in a
US population sample to be 520 per 100,000 [19]. Data from the 2009-2010 National Health and Nutrition Examination Survey (NHANES; a cross-sectional survey of the civilian, non-institutionalized US population) indicated that the population prevalence of axSpA is 0.9 to $1.4 \%$ (i.e., $1.7-2.7$ million persons) [20]. A retrospective review of medical records of a random sample of 514 patients from US rheumatology practices who were identified as being at risk for axSpA (defined as age 18-44 years with chronic back pain) estimated the prevalence of axSpA to be $0.7 \%$ [11]. A recent analysis from the Northern California Kaiser Permanente database estimated that the diagnostic prevalence of axSpA in US healthcare settings is $0.2 \%$ and the diagnostic prevalence of AS is $0.1 \%$ [21].

The marked differences between estimates of diagnostic prevalence and population prevalence are concerning despite the fact that in almost any population, some patients with a particular disease remain undiagnosed or may not seek care [22]. Accounting for additional reasons for differences in prevalence are studies that were performed in different geographic regions, reporting of crude versus adjusted rates, and variability in classification criteria or case definitions used in different studies [20-22].

Other characteristics observed in patients with axSpA in the USA include a slightly lower mean age in women compared to men at AS disease onset ( 21.5 vs $23.6 ; P=0.03$ ) [23]. Women were also more likely to have a family history of AS (41.0 vs $24.6 \% ; P=0.002)$ and had less radiographic progression as measured by Bath Ankylosing Spondylitis Radiology Index ( $6.5 \mathrm{vs} 10.0 ; P<0.001)$ [23]. In a comparison of racial/ ethnic groups, axSpA was more common in non-Hispanic whites $(1.5 \%)$ and Mexican Americans $(1.5 \%)$ than in blacks/African Americans (0.9\%) [20]. This difference may be attributed to the lower frequency of human leukocyte antigen (HLA)-B27 in blacks/African Americans $(1.1 \%)$ than in non-Hispanic whites $(7.5 \%)$ or Mexican Americans (4.6\%) [24].

Data from national surveys, including NHANES and the National Health Interview Survey, estimate that the US prevalence of RA is $0.6 \%(\sim 1.3$ million persons) [19]. The higher reported US prevalence of axSpA versus RA is paradoxical given that the number of patients treated for axSpA in rheumatology practices is much lower than the number of patients treated for RA. For example, in a recent cross-sectional study of 573 patients seeking care at a university-based rheumatology practice in Oregon, $18 \%$ of patients had been diagnosed with RA, whereas only $5 \%$ had been diagnosed with AS [25].

Underrepresentation of axSpA in US rheumatology practices raises an important question: Where are these patients, and who is managing them? A retrospective analysis of data from 2000 to 2012 showed that only $37 \%$ of patients with AS were diagnosed by a rheumatologist [26]. The remaining $63 \%$ of patients were diagnosed 
by other providers, such as practitioners in primary care (26\%), chiropractic/physical therapy (7\%), orthopedic surgery $(4 \%)$, pain clinics $(4 \%)$, acute care $(3 \%)$, and other settings (19\%) [26]. Of the patients who were diagnosed with AS by other providers and subsequently saw a rheumatologist, $42 \%$ had their diagnosis of AS confirmed by the rheumatologist; the remaining 58\% were found to have other disorders, such as joint effusion, unspecified back disorder, RA, rheumatism not otherwise specified, osteoarthritis, and spondylosis [26]. A study by Hurwitz et al. looked at claims data for low back pain from 2000 to 2009 and examined patterns of care among different providers [27]. This study reported that patients with low back pain were most often seen by physicians, chiropractors, and physical therapists; the number of patients seen by each type of provider increased during the study [27]. Taken together, these studies indicate that patients with suspected axSpA in the USA commonly receive care from providers other than rheumatologists and that these providers may be unfamiliar with differentiating this condition from other common causes of back pain and, hence, miss the diagnosis of axSpA in a substantial proportion of patients.

Delayed diagnosis of axSpA is a major problem in the USA and other countries [28-30]. Recent data estimate that average US diagnostic delays may be as long as 14 years; however, early referral to a rheumatologist can significantly reduce these delays [26, 28]. In an insurance claims database analysis of patients with back pain referred to a rheumatologist with suspicion of axSpA, a diagnosis of AS was typically made within 1 month [26]. Thus, timely referral to a rheumatologist is recommended for all patients at the earliest signs of suspected axSpA [31]. Results from the Prevalence of axSpA (PROSpA) study indicated that US rheumatologists also frequently missed the diagnosis of axSpA in their existing patients who were being followed for other reasons [28]. Notably, $\sim 40 \%$ of patients in this study with a new diagnosis of axSpA were existing patients in rheumatology practices [28].

\section{Reasons for missed or delayed axSpA diagnosis in the USA}

Among the many reasons that axSpA is so commonly missed is that spinal pain, the primary symptom of axSpA, affects approximately $80 \%$ of all adults at some point in their lifetimes [32]. Additionally, chronic low back pain affects $13 \%$ of adults [33]. AxSpA accounts for only 5\% of all chronic back pain $[13,14]$. The commonality of mechanical causes of back pain in the USA has led to an uncommon diagnosis such as axSpA being missed or considered late in the disease.

\section{Lack of validated diagnostic criteria}

Perhaps the simplest, most selective initial criteria for making the diagnosis of axSpA are patients' age and the nature of back pain at disease onset. In most (90-95\%) patients with axSpA, the disease starts with an insidious onset of back pain before 45 years of age (average age at disease onset: $\sim 25-28$ years) $[34,35]$. Therefore, onset age and type of back pain are especially important considerations as part of a differential diagnosis. However, after screening patients based on age and type of back pain, differential diagnosis becomes challenging because no validated diagnostic criteria are in place $[36,37]$.

Several classification criteria have been developed for the identification of axSpA, including the modified New York (mNY), Amor, European Spondyloarthropathy Study Group, and the most recent Assessment of Spondyloarthritis international Society (ASAS) criteria [37-40]. These classification criteria were developed mainly to have uniform patient populations for clinical research and clinical trials; they should not be used for making the diagnosis of axSpA due to intrinsic limitations. The $\mathrm{mNY}$ criteria are limited by poor sensitivity and the inability to identify patients in the non-radiographic stage of disease [4, 38, 41]. Additionally, although ASAS classification criteria have very good sensitivity and specificity [41], there are various reasons why they should not be used for diagnostic purposes. Specifically, certain parts of the criteria, including IBP, family history of SpA, good response to non-steroidal anti-inflammatory drugs, and the presence of enthesitis, lack objectivity and may lead to the misclassification of mechanical back pain or fibromyalgia as nr-axSpA [42]. Additionally, the "positive MRI" definition of the ASAS classification criteria is quite non-specific because mild inflammatory changes of the SIJs can be seen in healthy individuals and athletes, as well as in a wide range of pathologies (e.g., mechanical stresses, trauma, degenerative arthritis of SIJs) [43-45]. Hence, the use of positive MRI findings by ASAS criteria alone as a diagnostic test can result in a substantial overdiagnosis of axSpA [43, 45]. Additionally, interobserver differences in the interpretation of $\mathrm{x}$-ray images and MRIs of SIJs and a lack of formal training of rheumatologists and radiologists in reading these images can also contribute to misclassification.

\section{Limitations of physical examination}

There are significant limitations to the physical examination of patients with suspected axSpA. It is simply not possible for clinicians to examine SIJs and the spine for presence of inflammation in the same way that peripheral joints are examined in RA. Thus, manual clinical assessments are limited to physical maneuvers (e.g., pain provocation, spinal mobility, functional tests) $[46,47]$. However, none of these physical examination techniques, including spine mobility measurements, reliably 


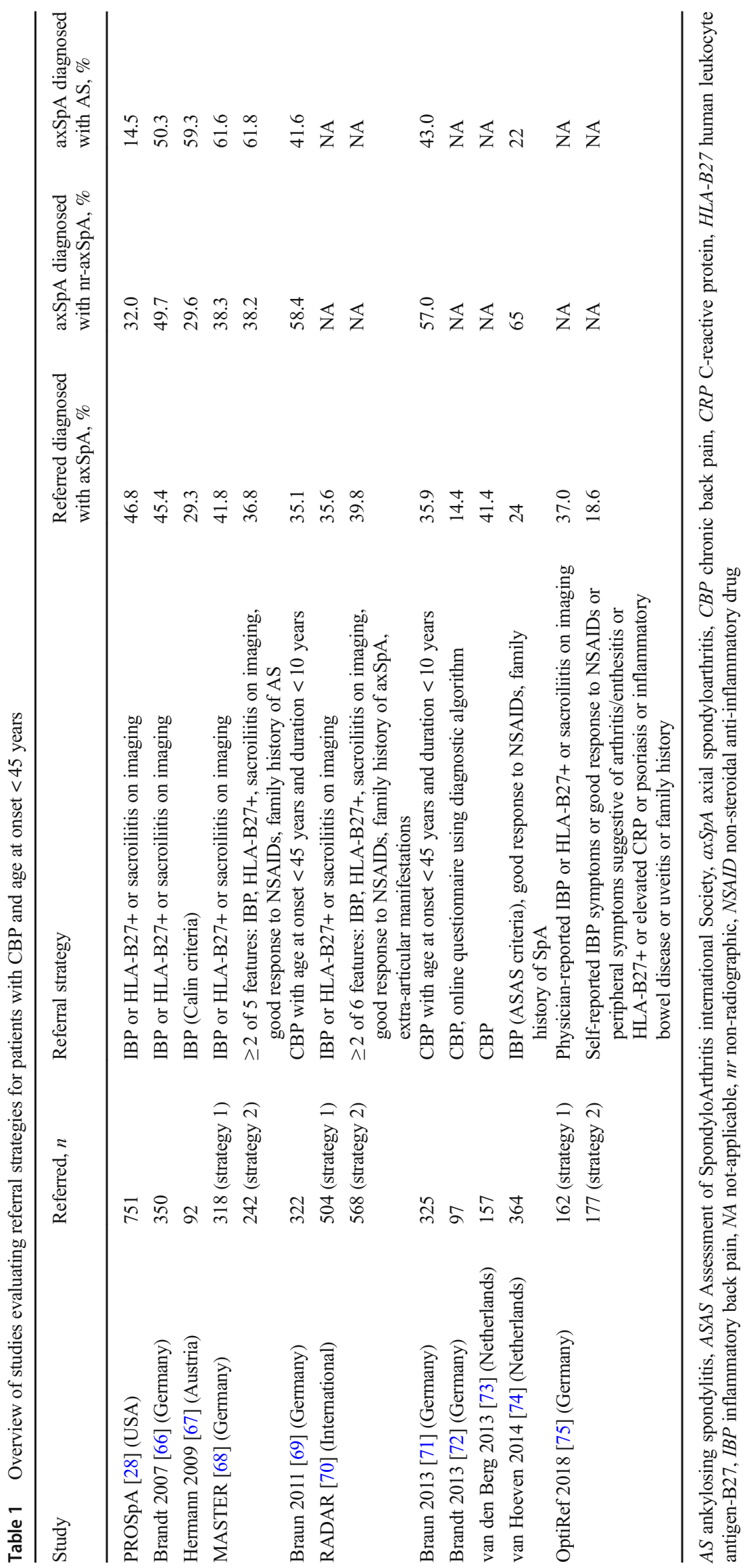


distinguish inflammatory diseases of the spine, such as axSpA, from common degenerative diseases of the spine.

\section{Lack of reliable biomarkers}

The availability and utility of serum and imaging biomarkers are limited in axSpA, especially compared with other rheumatic conditions (e.g., RA) [48, 49]. Currently, HLA-B27 and C-reactive protein are the two most commonly used serum biomarkers, and MRI scans of the SIJs are the most sensitive imaging biomarker $[50,51]$. NHANES data indicate that $6.1 \%$ of the general US population is HLA-B27 positive [24], but a prevalence of $0.5 \%$ [52] for AS would account for only $8 \%$ of
HLA-B27-positive individuals. Traditional radiography is an inexpensive way to identify joint damage caused by sacroiliitis, and radiographic findings can inform decisions about the need for more advanced imaging [14, 53]. However, traditional radiography is associated with intraand inter-reader variability and poor sensitivity in axSpA [14, 51, 53-55].

Alternatively, the specificity of finding inflammation of SIJs on MRI is low; relying on MRI findings for diagnosis of axSpA can result in overdiagnosis or misclassification of axSpA [43, 56-58]. Therefore, it is necessary for biomarkers to be interpreted in the context of other clinical features that suggest a diagnosis of axSpA.

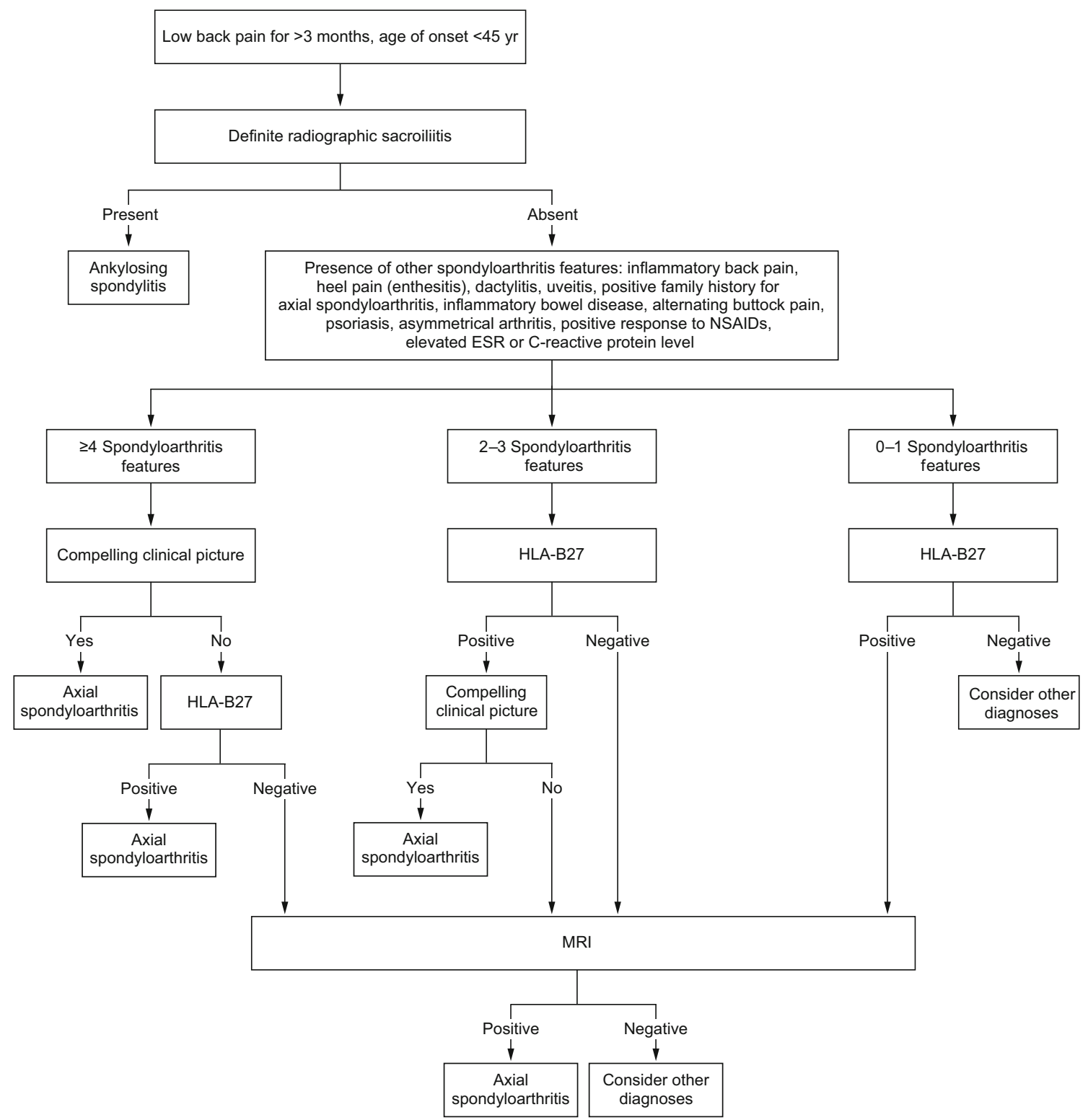

Fig. 1 ASAS modification of the Berlin Algorithm for diagnosis of axSpA from Taurog et al. [77]. Reprinted with permission from Massachusetts Medical Society. ASAS Assessment of SpondyloArthritis international Society, axSpA axial spondyloarthritis, ESR erythrocyte sedimentation rate, $H L A-B 27$ human leukocyte antigen-B27, MRI magnetic resonance imaging 


\section{Patient and practitioner factors}

Historically, US patients with low back pain seek medical care from primary care physicians, orthopedists, chiropractors, or complementary/alternative medicine practitioners (e.g., osteopaths, massage therapists, acupuncturists) $[59,60]$. A 2016 survey of 7645 US adults found that if out-of-pocket costs were equal, people were most likely to choose physicians (53\%) if they had neck or back pain, followed by chiropractors $(28 \%)$, massage therapists $(7 \%)$, physical therapists $(6 \%)$, and acupuncturists (1\%) [61]. A previous study showed that Americans are increasingly choosing to see chiropractors for routine care if it is covered by health insurance, especially in rural areas where people may not have access to medical specialists $[62,63]$. Complementary and alternative medicine is also gaining popularity, in part, because it can be less expensive than traditional care for many patients with back pain. Patients with axSpA may also seek initial care from specialists (e.g., ophthalmologists, gastroenterologists, dermatologists) regarding associated disease manifestations, including uveitis, inflammatory bowel disease, and psoriasis, respectively [64, 65]. In general, these practitioners and specialists may be unfamiliar with recognizing symptoms of back pain specific to axSpA [65].

Table 2 Ankylosing spondylitis case ascertainment tool and scoring algorithm [79]

\begin{tabular}{|c|c|c|}
\hline Question item & Response categories & Item score \\
\hline What is your gender? & $\begin{array}{l}\text { Male } \\
\text { Female }\end{array}$ & $\begin{array}{l}1.2397 \\
0\end{array}$ \\
\hline \multicolumn{3}{|l|}{$\begin{array}{l}\text { Have you experienced pain or stiffness that lasted for } \geq 3 \text { months? If so, } \\
\text { please indicate the location(s). }\end{array}$} \\
\hline Neck & Yes/no & Yes $=1.2502$ \\
\hline Hip & Yes/no & Yes $=1.2644$ \\
\hline Other regions & Yes/no & Yes $=0.9421$ \\
\hline $\begin{array}{l}\text { Approximately how old were you when you first had pain or stiffness in } \\
\text { your back that lasted } \geq 3 \text { months? }\end{array}$ & In years & $-0.0747 \times($ number of years $)$ \\
\hline Approximately how long have you had back pain or stiffness? & In months & $0.00374 \times($ number of months $)$ \\
\hline $\begin{array}{l}\text { Have you felt numbness or tingling that spread into or down } \\
\text { your leg(s) that you think or have been told might have been } \\
\text { caused by your back pain or stiffness? }\end{array}$ & Yes/no & Yes $=-1.0214$ \\
\hline $\begin{array}{l}\text { Is the pain or stiffness due to a fall, sprain, or other incidents, such as } \\
\text { twisting or lifting? }\end{array}$ & Yes/no & Yes $=-1.3775$ \\
\hline $\begin{array}{l}\text { How does exercise affect the pain or stiffness in your lower back or } \\
\text { buttocks? Select the one that best describes your experience. }\end{array}$ & $\begin{array}{l}\text { - It decreases the pain or stiffness } \\
\text { - It does not change the pain or stiffness } \\
\text { - It increases the pain or stiffness } \\
\text { - I do not have pain or stiffness in the lower } \\
\text { back or buttocks }\end{array}$ & $\begin{array}{l}-1.5437 \\
0 \\
-2.6988 \\
0\end{array}$ \\
\hline $\begin{array}{l}\text { How does daily physical activity affect the pain or stiffness in your lower } \\
\text { back or buttocks? Select the one that best describes your experience. }\end{array}$ & $\begin{array}{l}\text { - It decreases the pain or stiffness } \\
\text { - It does not change the pain or stiffness } \\
\text { - It increases the pain or stiffness } \\
\text { - I do not have pain or stiffness in the lower } \\
\text { back or buttocks }\end{array}$ & $\begin{array}{l}2.1178 \\
0 \\
1.0141 \\
0\end{array}$ \\
\hline $\begin{array}{l}\text { Do you take any NSAIDs? If so, do they help reduce your } \\
\text { back pain or stiffness within } 48 \text { h? }\end{array}$ & $\begin{array}{l}\text { - Yes, they help reduce my back pain or } \\
\text { stiffness within } 48 \mathrm{~h} \\
\text { - No, they do not help reduce my back pain } \\
\text { or stiffness within } 48 \mathrm{~h} \\
\text { - I do not take an NSAID }\end{array}$ & $\begin{array}{l}0.3293 \\
-2.1489 \\
0\end{array}$ \\
\hline Have you been diagnosed with iritis? & Yes/no & Yes $=3.4113$ \\
\hline $\begin{array}{l}\text { Scoring algorithm } \\
1 \text { Assign an item score for each of the patient's responses. } \\
2 \text { Take the sum of the patient's item scores. Let } x \text { be the sum of the } \\
\text { patient's item scores. } \\
3 \text { Let } y \text { be the patient's transformed score. We calculate } y \text { as follows: }\end{array}$ & & \\
\hline $\begin{aligned} y= & \frac{e^{x-1.0242}}{1+e^{x-1.0242}} \times 100 \\
& \text { (Note: }-1.0242 \text { is the intercept of the logistic regression mode.) } \\
& 4 \text { If } y \geq 66.86 \text {, then the case ascertainment tool result is positive for AS. }\end{aligned}$ & & \\
\hline
\end{tabular}

From Weisman et al. [79]. Reprinted with permission from John Wiley \& Sons, Inc.

$A S$ ankylosing spondylitis, NSAID non-steroidal anti-inflammatory drug 


\section{The way forward}

Given the unfamiliarity regarding differences between mechanical back pain and IBP among HCPs, public health initiatives are needed to educate non-rheumatologists (primary care physicians and specialists such as in dermatology, gastroenterology, ophthalmology, orthopedics, spinal surgery) on ways to identify patients with axSpA [65]. Table 1 provides an overview of studies that have evaluated referral strategies for patients with chronic back pain and age at onset $<45$ years. Application of these different referral strategies to the patients in the SPACE cohort showed that most of these models had good sensitivity and specificity [76]. Most of the studies listed in Table 1 were conducted in Europe, with only the PROSpA study providing data on US referral practices and patterns [28]. PROSpA was a study conducted at 68 rheumatology practices across the USA that enrolled 751 patients with chronic ( $\geq 3$ months) back pain that began at age $<45$ years. Within this cohort, $46 \%$ (319 of 697) of patients with available data were diagnosed by the study investigator as having axSpA, and $46.8 \%$ (348 of 744) fulfilled ASAS axSpA classification criteria. These findings indicate that the presence of $\geq 1$ of $3 \mathrm{SpA}$ features (HLA-B27 positivity, current IBP, or MRI evidence of sacroiliitis) is an effective way to suspect possible axSpA, and these patients should be referred to a rheumatologist [28].

Recognizing the need for enhanced awareness and understanding of axSpA and AS, Taurog and colleagues recently published a modification of the ASAS algorithm for diagnosis of axSpA in patients with chronic back pain that initiated at age < 45 years (Fig. 1) [77]. When compared with an external standard rheumatologist diagnosis, the algorithm on which Fig. 1 is based resulted in an $8.9 \%$ false-negative and an $11.5 \%$ false-positive diagnosis rate in the SPACE cohort and a $12.7 \%$ false-negative and a $9.8 \%$ false-positive diagnosis rate in a larger ASAS cohort [73]. Algorithms such as this can be valuable tools when combined with a comprehensive diagnostic workup and consideration of alternative diagnoses [78].

Research efforts supported by the Spondylitis Association of America led to the development of a case ascertainment tool that patients can use for self-identification (Table 2) [79]. It was hoped that use of this tool would result in earlier and more accurate diagnosis of axSpA, but the instrument is cumbersome and, thus, has not been widely incorporated into daily clinical practice. A patient-reported clinical screening tool, such as a questionnaire without the use of imaging or laboratory tests with high sensitivity and reasonable specificity, is needed for use in non-rheumatologic practices to identify patients with suspected axSpA. An instrument of this type could facilitate easier decision-making regarding referral of appropriate patients to a rheumatologist for diagnosis of axSpA. Additionally, administrative healthcare codes for diagnosing AS have high predictive value for identifying these patients, but, in general, the lack of specific diagnostic codes limits the utility of healthcare databases to study axSpA [80].

In conclusion, much progress has been made in recent years in understanding the importance of early axSpA diagnosis and in identifying many of the hurdles that contribute to diagnostic delays in the USA. By implementing the tools and strategies outlined in this review, it is hoped that future diagnostic delays will be reduced or eliminated in patients with axSpA.

Acknowledgments Technical assistance with editing and styling of the manuscript for submission was provided by Oxford PharmaGenesis Inc. and was funded by Novartis Pharmaceuticals Corporation. The authors were fully responsible for all content and editorial decisions and received no financial support or other form of compensation related to the development of this manuscript.

Data availability Data sharing is not applicable to this article as no datasets were generated or analyzed during the current study.

\section{Role of funding source}

The funding source had no involvement in the writing of the manuscript or in the decision to submit the article for publication.

\section{Compliance with ethical standards}

This manuscript does not contain clinical studies or patient data.

Disclosures Dr. Danve has received research grants from or has served on an advisory board for Janssen and Novartis. Dr. Deodhar has received research grants from and has served on advisory boards for AbbVie, Bristol Myers Squibb, Eli Lilly, Janssen, Novartis, Pfizer, and UCB.

Open Access This article is distributed under the terms of the Creative Commons Attribution 4.0 International License (http:// creativecommons.org/licenses/by/4.0/), which permits unrestricted use, distribution, and reproduction in any medium, provided you give appropriate credit to the original author(s) and the source, provide a link to the Creative Commons license, and indicate if changes were made.

Publisher's note Springer Nature remains neutral with regard to jurisdictional claims in published maps and institutional affiliations.

\section{References}

1. Strand V, Singh JA (2017) Evaluation and management of the patient with suspected inflammatory spine disease. Mayo Clin Proc 92:555-564. https://doi.org/10.1016/j.mayocp.2016.12.008

2. Sieper J, van der Heijde D, Landewé R, Brandt J, Burgos-Vagas R, Collantes-Estevez E, Dijkmans B, Dougados M, Khan MA, Leirisalo-Repo M, van der Linden S, Maksymowych WP, Mielants H, Olivieri I, Rudwaleit M (2009) New criteria for inflammatory back pain in patients with chronic back pain: a real patient exercise by experts from the Assessment of SpondyloArthritis international Society (ASAS). Ann Rheum Dis 68:784-788. https:// doi.org/10.1136/ard.2008.101501

3. Keith MP (2012) Inflammatory back pain and the diagnosis of axial spondyloarthritis. Am J Orthop (Belle Mead NJ) 41:E166-E168

4. Rudwaleit M, Metter A, Listing J, Sieper J, Braun J (2006) Inflammatory back pain in ankylosing spondylitis: a reassessment 
of the clinical history for application as classification and diagnostic criteria. Arthritis Rheum 54:569-578. https://doi.org/10.1002/art. 21619

5. Deodhar A, Strand V, Kay J, Braun J (2016) The term 'nonradiographic axial spondyloarthritis' is much more important to classify than to diagnose patients with axial spondyloarthritis. Ann Rheum Dis 75:791-794. https://doi.org/10.1136/ annrheumdis-2015-208852

6. Ciurea A, Scherer A, Exer P, Bernhard J, Dudler J, Beyeler B, Kissling R, Stekhoven D, Rufibach K, Tamborrini G, Weiss B, Müller R, Nissen MJ, Michel BA, van der Heijde D, Dougados M, Boonen A, Weber U, Rheumatologists of the Swiss Clinical Quality Management Program for Axial Spondyloarthritis (2013) Tumor necrosis factor alpha inhibition in radiographic and nonradiographic axial spondyloarthritis: results from a large observational cohort. Arthritis Rheum 65:3096-3106. https://doi.org/10. 1002/art.38140

7. Barkham N, Keen HI, Coates LC, O'Connor P, Hensor E, Fraser AD, Cawkwell LS, Bennett A, McGonagle D, Emery P (2009) Clinical and imaging efficacy of infliximab in HLA-B27-positive patients with magnetic resonance imaging-determined early sacroiliitis. Arthritis Rheum 60:946-954. https://doi.org/10.1002/ art.24408

8. Braun J, Baraliakos X, Kiltz U (2016) Non-radiographic axial spondyloarthritis: a classification or a diagnosis? Clin Exp Rheumatol 34:S5-S6

9. Erbil J, Espinoza LR (2015) Nonradiographic axial spondyloarthritis background and confounding factors of this new terminology: an appraisal. Clin Rheumatol 34:407-411. https://doi.org/10.1007/s10067-014-2787-8

10. Weisman MH, Witter JP, Reveille JD (2013) The prevalence of inflammatory back pain: population-based estimates from the US National Health and Nutrition Examination Survey, 2009-10. Ann Rheum Dis 72:369-373. https://doi.org/10.1136/annrheumdis2012-201403

11. Strand V, Rao SA, Shillington AC, Cifaldi MA, McGuire M, Ruderman EM (2013) Prevalence of axial spondyloarthritis in United States rheumatology practices: Assessment of SpondyloArthritis International Society criteria versus rheumatology expert clinical diagnosis. Arthritis Care Res (Hoboken) 65: 1299-1306. https://doi.org/10.1002/acr.21994

12. Hunter TM, Boytsov NN, Zhang X, Schroeder K, Michaud K, Araujo AB (2017) Prevalence of rheumatoid arthritis in the United States adult population in healthcare claims databases, 2004-2014. Rheumatol Int 37:1551-1557. https://doi.org/10.1007/ s00296-017-3726-1

13. Underwood MR, Dawes P (1995) Inflammatory back pain in primary care. Br J Rheumatol 34:1074-1077

14. Bernard SA, Kransdorf MJ, Beaman FD, Adler RS, Amini B, Appel M, Arnold E, Cassidy RC, Greenspan BS, Lee KS, Tuite MJ, Walker EA, Ward RJ, Wessell DE, Weissman BN (2017) ACR Appropriateness Criteria ${ }^{\circledR}$ chronic back pain suspected sacroiliitisspondyloarthropathy. J Am Coll Radiol 14:S62-S70. https://oi. org/10.1016/j.jacr.2017.01.048

15. Seo MR, Baek HL, Yoon HH, Ryu HJ, Choi HJ, Baek HJ, Ko KP (2015) Delayed diagnosis is linked to worse outcomes and unfavourable treatment responses in patients with axial spondyloarthritis. Clin Rheumatol 34:1397-1405. https://doi.org/ 10.1007/s10067-014-2768-y

16. Maksymowych WP, Morency N, Conner-Spady B, Lambert RG (2013) Suppression of inflammation and effects on new bone formation in ankylosing spondylitis: evidence for a window of opportunity in disease modification. Ann Rheum Dis 72:23-28. https:// doi.org/10.1136/annrheumdis-2011-200859
17. Carter ET, McKenna CH, Brian DD, Kurland LT (1979) Epidemiology of ankylosing spondylitis in Rochester, Minnesota, 1935-1973. Arthritis Rheum 22:365-370

18. Carbone LD, Cooper C, Michet CJ, Atkinson EJ, O'Fallon WM, Melton LJ 3rd (1992) Ankylosing spondylitis in Rochester, Minnesota, 1935-1989. Is the epidemiology changing? Arthritis Rheum 35:1476-1482

19. Helmick CG, Felson DT, Lawrence RC, Gabriel S, Hirsch R, Kwoh CK, Liang MH, Kremers HM, Mayes MD, Merkel PA, Pillemer SR, Reveille JD, Stone JH, Workgroup NAD (2008) Estimates of the prevalence of arthritis and other rheumatic conditions in the United States. Part I. Arthritis Rheum 58:15-25. https://doi.org/ 10.1002/art.23177

20. Reveille JD, Witter JP, Weisman MH (2012) Prevalence of axial spondylarthritis in the United States: estimates from a crosssectional survey. Arthritis Care Res (Hoboken) 64:905-910. https://doi.org/10.1002/acr.21621

21. Curtis JR, Harrold LR, Asgari MM, Deodhar A, Salman C, Gelfand JM, Wu JJ, Herrinton LJ (2016) Diagnostic prevalence of ankylosing spondylitis using computerized health care data, 1996 to 2009: underrecognition in a US health care setting. Perm J 20:4-10. https://doi.org/10.7812/TPP/15-151

22. Bohn R, Cooney M, Deodhar A, Curtis JR, Golembesky A (2018) Incidence and prevalence of axial spondyloarthritis: methodologic challenges and gaps in the literature. Clin Exp Rheumatol 36:263274

23. Lee W, Reveille JD, Davis JC Jr, Learch TJ, Ward MM, Weisman MH (2007) Are there gender differences in severity of ankylosing spondylitis? Results from the PSOAS cohort. Ann Rheum Dis 66: 633-638. https://doi.org/10.1136/ard.2006.060293

24. Reveille JD, Hirsch R, Dillon CF, Carroll MD, Weisman MH (2012) The prevalence of HLA-B27 in the US: data from the US National Health and Nutrition Examination Survey, 2009. Arthritis Rheum 64:1407-1411. https://doi.org/10.1002/art.33503

25. Ku JH, Danve A, Pang H, Choi D, Rosenbaum JT (2015) Determinants of patient satisfaction in an academic rheumatology practice. J Clin Rheumatol 21:256-262. https://doi.org/10.1097/ RHU.0000000000000263

26. Deodhar A, Mittal M, Reilly P, Bao Y, Manthena S, Anderson J, Joshi A (2016) Ankylosing spondylitis diagnosis in US patients with back pain: identifying providers involved and factors associated with rheumatology referral delay. Clin Rheumatol 35:17691776. https://doi.org/10.1007/s10067-016-3231-z

27. Hurwitz EL, Li D, Guillen J, Schneider MJ, Stevans JM, Phillips RB, Phelan SP, Lewis EA, Armstrong RC, Vassilaki M (2016) Variations in patterns of utilization and charges for the care of low back pain in North Carolina, 2000 to 2009: a statewide claims' data analysis. J Manip Physiol Ther 39:252-262. https://doi.org/10. 1016/j.jmpt.2016.02.006

28. Deodhar A, Mease PJ, Reveille JD, Curtis JR, Chen S, Malhotra K, Pangan AL (2016) Frequency of axial spondyloarthritis diagnosis among patients seen by US rheumatologists for evaluation of chronic back pain. Arthritis Rheumatol 68:1669-1676. https://doi.org/10. 1002/art.39612

29. Sykes MP, Doll H, Sengupta R, Gaffney K (2015) Delay to diagnosis in axial spondyloarthritis: are we improving in the UK? Rheumatology (Oxford) 54:2283-2284. https://doi.org/10.1093/ rheumatology/kev288

30. Fallahi S, Jamshidi AR (2016) Diagnostic delay in ankylosing spondylitis: related factors and prognostic outcomes. Arch Rheumatol 31(x):i-vii

31. Danve A, Deodhar A (2015) Screening and referral for axial spondyloarthritis — need of the hour. Clin Rheumatol 34:987-993. https://doi.org/10.1007/s10067-015-2958-2 
32. Manchikanti L, Singh V, Datta S, Cohen SP, Hirsch JA (2009) Comprehensive review of epidemiology, scope, and impact of spinal pain. Pain Physician 12:E35-E70

33. Shmagel A, Foley R, Ibrahim H (2016) Epidemiology of chronic low back pain in US adults: data from the 2009-2010 National Health and Nutrition Examination Survey. Arthritis Care Res (Hoboken) 68:1688-1694. https://doi.org/10.1002/acr.22890

34. Sieper J (2012) How to screen for axial spondyloarthritis in primary care? Curr Opin Rheumatol 24:359-362. https://doi.org/10.1097/ BOR.0b013e328352e0ee

35. Feldtkeller E, Khan MA, van der Heijde D, van der Linden S, Braun $\mathrm{J}$ (2003) Age at disease onset and diagnosis delay in HLA-B27 negative vs. positive patients with ankylosing spondylitis. Rheumatol Int 23:61-66. https://doi.org/10.1007/s00296-002$0237-4$

36. Slobodin G, Rosner I (2013) Indemonstrable axial spondyloarthritis: does it exist? Isr Med Assoc J 15:780-781

37. Rudwaleit M, van der Heijde D, Landewé R, Listing J, Akkoc N, Brandt J, Braun J, Chou CT, Collantes-Estevez E, Dougados M, Huang F, Gu J, Khan MA, Kirazli Y, Maksymowych WP, Mielants H, Sørensen IJ, Ozgocmen S, Roussou E, Valle-Oñate R, Weber U, Wei J, Sieper J (2009) The development of Assessment of SpondyloArthritis international Society classification criteria for axial spondyloarthritis (part II): validation and final selection. Ann Rheum Dis 68:777-783. https://doi.org/10.1136/ard.2009.108233

38. van der Linden S, Valkenburg HA, Cats A (1984) Evaluation of diagnostic criteria for ankylosing spondylitis. A proposal for modification of the New York criteria. Arthritis Rheum 27:361-368

39. Amor B, Dougados M, Mijiyawa M (1990) Criteria of the classification of spondylarthropathies. Rev Rhum Mal Osteoartic 57:8589

40. Dougados M, van der Linden S, Juhlin R, Huitfeldt B, Amor B, Calin A, Cats A, Dijkmans B, Olivieri I, Pasero G, Veys E, Zeidler H, The European Spondylarthropathy Study Group (1991) The European Spondylarthropathy Study Group preliminary criteria for the classification of spondylarthropathy. Arthritis Rheum 34: $1218-1227$

41. Akgul O, Ozgocmen S (2011) Classification criteria for spondyloarthropathies. World J Orthop 2:107-115. https://doi. org/10.5312/wjo.v2.i12.07

42. Deodhar A (2014) Axial spondyloarthritis criteria and modified NY criteria: issues and controversies. Clin Rheumatol 33:741-747. https://doi.org/10.1007/s10067-014-2661-8

43. Deodhar A (2016) Sacroiliac joint magnetic resonance imaging in the diagnosis of axial spondyloarthritis: "a tiny bit of white on two consecutive slices" may be objective, but not specific. Arthritis Rheumatol 68:775-778. https://doi.org/10.1002/art.39549

44. Weber U, Jurik AG, Zejden A, Larsen E, Jørgensen SH, Rufibach K, Schioldan C, Schmidt-Olsen S (2018) Frequency and anatomic distribution of magnetic resonance imaging features in the sacroiliac joints of young athletes: exploring "background noise" toward a data-driven definition of sacroiliitis in early spondyloarthritis. Arthritis Rheumatol 70:736-745. https://doi.org/10.1002/art.40429

45. Weber U, Lambert RG, Østergaard M, Hodler J, Pedersen SJ, Maksymowych WP (2010) The diagnostic utility of magnetic resonance imaging in spondylarthritis: an international multicenter evaluation of one hundred eighty-seven subjects. Arthritis Rheum 62:3048-3058. https://doi.org/10.1002/art.27571

46. Castro MP, Stebbings SM, Milosavljevic S, Bussey MD (2015) Role of physical evaluation in the early identification of axial spondyloarthritis: a research proposal. Clin Med Insights Arthritis Musculoskelet Disord 8:59-64. https://doi.org/10.4137/CMAMD. S28347

47. Zochling J, Braun J (2005) Assessment of ankylosing spondylitis. Clin Exp Rheumatol 23:S133-S141
48. Aletaha D, Neogi T, Silman AJ, Funovits J, Felson DT, Bingham CO III, Birnbaum NS, Burmester GR, Bykerk VP, Cohen MD, Combe B, Costenbader KH, Dougados M, Emery P, Ferraccioli G, Hazes JMW, Hobbs K, Huizinga TWJ, Kavanaugh A, Kay J, Kvien TK, Laing T, Mease P, Ménard HA, Moreland LW, Naden RL, Pincus T, Smolen JS, Stanislawska-Biernat E, Symmons D, Tak PP, Upchurch KS, Vencovský J, Wolfe F, Hawker G et al (2010) 2010 rheumatoid arthritis classification criteria: an American College of Rheumatology/European League Against Rheumatism collaborative initiative. Arthritis Rheum 62:25692581. https://doi.org/10.1002/art.27584

49. Taylor P, Gartemann J, Hsieh J, Creeden J (2011) A systematic review of serum biomarkers anti-cyclic citrullinated peptide and rheumatoid factor as tests for rheumatoid arthritis. Autoimmune Dis 2011:815038-815018. https://doi.org/10.4061/2011/815038

50. Danve A, O'Dell J (2015) The ongoing quest for biomarkers in ankylosing spondylitis. Int J Rheum Dis 18:826-834. https://doi. org/10.1111/1756-185X.12779

51. Diekhoff T, Hermann KG, Greese J, Schwenke C, Poddubnyy D, Hamm B, Sieper J (2017) Comparison of MRI with radiography for detecting structural lesions of the sacroiliac joint using CT as standard of reference: results from the SIMACT study. Ann Rheum Dis 76:1502-1508. https://doi.org/10.1136/annrheumdis-2016-210640

52. Reveille JD (2011) Epidemiology of spondyloarthritis in North America. Am J Med Sci 341:284-286. https://doi.org/10.1097/ MAJ.0b013e31820f8c99

53. Pialat JB, Di Marco L, Feydy A, Peyron C, Porta B, Himpens PH, Ltaief-Boudrigua A, Aubry S (2016) Sacroiliac joints imaging in axial spondyloarthritis. Diagn Interv Imaging 97:697-708. https:// doi.org/10.1016/j.diii.2016.02.013

54. van Tubergen A, Heuft-Dorenbosch L, Schulpen G, Landewé R, Wijers R, van der Heijde D, van Engelshoven J, van der Linden S (2003) Radiographic assessment of sacroiliitis by radiologists and rheumatologists: does training improve quality? Ann Rheum Dis 62:519-525

55. Christiansen AA, Hendricks O, Kuettel D, Hørslev-Petersen K, Jurik AG, Nielsen S, Rufibach K, Loft AG, Pedersen SJ, Hermansen LT, Østergaard M, Arnbak B, Manniche C, Weber U (2017) Limited reliability of radiographic assessment of sacroiliac joints in patients with suspected early spondyloarthritis. J Rheumatol 44:70-77. https://doi.org/10.3899/jrheum.160079

56. de Winter J, de Hooge M, van de Sande M, van Hoeven L, de Jong J, de Koning A, Berg IJ, Ramonda R, Baeten D, van der Heijde D, Weel A, Landewé RBM (2017) A positive MRI of the sacroiliac joints is not specific for axial spondyloarthritis but frequently occurs in healthy individuals [abstract]. Arthritis Rheumatol 69(Suppl 10): Abstract 1831

57. Arnbak B, Grethe Jurik A, Horslev-Petersen K, Hendricks O, Hermansen LT, Loft AG, Østergaard M, Pedersen SJ, Zejden A, Egund N, Holst R, Manniche C, Jensen TS (2016) Associations between spondyloarthritis features and magnetic resonance imaging findings: a cross-sectional analysis of 1,020 patients with persistent low back pain. Arthritis Rheumatol 68:892-900. https://doi. org/10.1002/art.39551

58. Dubreuil M, Deodhar AA (2017) Axial spondyloarthritis classification criteria: the debate continues. Curr Opin Rheumatol 29:317322. https://doi.org/10.1097/BOR.0000000000000402

59. Wolsko PM, Eisenberg DM, Davis RB, Kessler R, Phillips RS (2003) Patterns and perceptions of care for treatment of back and neck pain: results of a national survey. Spine (Phila Pa 1976) 28: 292-297; discussion 298. https://doi.org/10.1097/01.BRS. 0000042225.88095.7C

60. Deyo RA, Tsui-Wu YJ (1987) Descriptive epidemiology of lowback pain and its related medical care in the United States. Spine (Phila Pa 1976) 12:264-268 
61. Gallup-Palmer College of Chiropractic Annual Report: Americans' perceptions of chiropractic. Gallup, Inc. http://www.palmer.edu/ uploadedFiles/Pages/Alumni/gallup-report-palmer-college-2016. pdf. Accessed 9 May 2018

62. Weeks WB, Goertz CM, Meeker WC, Marchiori DM (2015) Public perceptions of doctors of chiropractic: results of a national survey and examination of variation according to respondents' likelihood to use chiropractic, experience with chiropractic, and chiropractic supply in local health care markets. J Manip Physiol Ther 38:533544. https://doi.org/10.1016/j.jmpt.2015.08.001

63. Lind BK, Diehr PK, Grembowski DE, Lafferty WE (2009) Chiropractic use by urban and rural residents with insurance coverage. J Rural Health 25:253-258. https://doi.org/10.1111/j.17480361.2009.00227.x

64. Danve A, Raychaudhuri SP (2017) Comorbidities in spondyloarthritis. Curr Treat Options in Rheum 3:63-74

65. Mathieson HR, Merashli M, Gaffney K, Marzo-Ortega H, BRITSpA (British Society for Spondyloarthritis) (2016) Poor awareness of inflammatory back pain and axial spondyloarthritis among secondary care specialists. Clin Rheumatol 35:2627-2628. https://doi.org/10.1007/s10067-016-3305-y

66. Brandt HC, Spiller I, Song IH, Vahldiek JL, Rudwaleit M, Sieper J (2007) Performance of referral recommendations in patients with chronic back pain and suspected axial spondyloarthritis. Ann Rheum Dis 66:1479-1484. https://doi.org/10.1136/ard.2006. 068734

67. Hermann J, Giessauf H, Schaffler G, Ofner P, Graninger W (2009) Early spondyloarthritis: usefulness of clinical screening. Rheumatology (Oxford) 48:812-816. https://doi.org/10.1093/ rheumatology/kep119

68. Poddubnyy D, Vahldiek J, Spiller I, Buss B, Listing J, Rudwaleit M, Sieper J (2011) Evaluation of 2 screening strategies for early identification of patients with axial spondyloarthritis in primary care. $\mathrm{J}$ Rheumatol 38:2452-2460. https://doi.org/10.3899/jrheum.110070

69. Braun A, Saracbasi E, Grifka J, Schnitker J, Braun J (2011) Identifying patients with axial spondyloarthritis in primary care: how useful are items indicative of inflammatory back pain? Ann Rheum Dis 70:1782-1787. https://doi.org/10.1136/ard.2011. 151167

70. Sieper J, Srinivasan S, Zamani O, Mielants H, Choquette D, Pavelka K, Loft AG, Géher P, Danda D, Reitblat T, Cantini F, Ancuta C, Erdes S, Raffayová H, Keat A, Gaston JS, Praprotnik S, Vastesaeger N (2013) Comparison of two referral strategies for diagnosis of axial spondyloarthritis: the Recognising and Diagnosing Ankylosing Spondylitis Reliably (RADAR) study. Ann Rheum Dis 72:1621-1627. https://doi.org/10.1136/ annrheumdis-2012-201777

71. Braun A, Gnann H, Saracbasi E, Grifka J, Kiltz U, Letschert K, Braun J (2013) Optimizing the identification of patients with axial spondyloarthritis in primary care - the case for a two-step strategy combining the most relevant clinical items with HLA B27. Rheumatology (Oxford) 52:1418-1424. https://doi.org/10.1093/ rheumatology/ket115

72. Brandt H, Vahldiek J, Rudwaleit M, Sieper J (2013) Performance of a patient-based online-questionnaire to identify patients with axial spondyloarthritis (SPA) in patients with chronic low back pain [abstract]. Ann Rheum Dis 71(Suppl 3):Abstract AB1266

73. van den Berg R, de Hooge M, Rudwaleit M, Sieper J, van Gaalen F, Reijnierse M, Landewé R, Huizinga T, van der Heijde D (2013) ASAS modification of the Berlin algorithm for diagnosing axial spondyloarthritis: results from the SPondyloArthritis Caught Early (SPACE)-cohort and from the Assessment of SpondyloArthritis international Society (ASAS)-cohort. Ann Rheum Dis 72:16461653. https://doi.org/10.1136/annrheumdis-2012-201884

74. van Hoeven L, Luime J, Han H, Vergouwe Y, Weel A (2014) Identifying axial spondyloarthritis in Dutch primary care patients, ages 20-45 years, with chronic low back pain. Arthritis Care Res (Hoboken) 66:446-453. https://doi.org/10.1002/acr.22180

75. Proft F, Spiller L, Protopopov M, Schmidt M, Rios Rodriguez V, Muche B, Rademacher J, Lüders S, Weber A-K, Spiller I, Sieper J, Poddubnyy D (2018) THU0230 performance of an online selfreferral questionnaire compared to a physician-based referral approach to identify patients with a high probability of axial spondyloarthritis: results from the optiref study. Ann Rheum Dis 77:335

76. Abawi O, van den Berg R, van der Heijde D, van Gaalen FA (2017) Evaluation of multiple referral strategies for axial spondyloarthritis in the SPondyloArthritis Caught Early (SPACE) cohort. RMD Open 3:e000389. https://doi.org/10.1136/rmdopen-2016-000389

77. Taurog JD, Chhabra A, Colbert RA (2016) Ankylosing spondylitis and axial spondyloarthritis. N Engl J Med 374:2563-2574. https:// doi.org/10.1056/NEJMra1406182

78. Ez-Zaitouni Z, Bakker PAC, van Lunteren M, Berg IJ, Landewé R, van Oosterhout M, Lorenzin M, van der Heijde D, van Gaalen FA (2017) Presence of multiple spondyloarthritis (SpA) features is important but not sufficient for a diagnosis of axial spondyloarthritis: data from the SPondyloArthritis Caught Early (SPACE) cohort. Ann Rheum Dis 76:1086-1092. https://doi.org/10.1136/ annrheumdis-2016-210119

79. Weisman MH, Chen L, Clegg DO, Davis JC Jr, Dubois RW, Prete PE, Savage LM, Schafer L, Suarez-Almazor ME, Yu HT, Reveille JD (2010) Development and validation of a case ascertainment tool for ankylosing spondylitis. Arthritis Care Res (Hoboken) 62:19-27. https://doi.org/10.1002/acr.20009

80. Wang R, Ward MM (2018) Epidemiology of axial spondyloarthritis: an update. Curr Opin Rheumatol 30:137-143. https://doi.org/10.1097/BOR.0000000000000475 